\title{
Expansion of Diplopterys at the Expense of Banisteriopsis (Malpighiaceae)
}

\section{Citation}

Anderson, William R. and Charles C. Davis. 2006. Expansion of Diplopterys at the expense of Banisteriopsis (Malpighiaceae). Harvard Papers in Botany 11(2): 1-16.

\section{Published Version}

http://dx.doi.org/10.3100/1043-4534(2006)95[1:EODATE]2.0.C0;2

\section{Permanent link}

http://nrs.harvard.edu/urn-3:HUL.InstRepos:2710468

\section{Terms of Use}

This article was downloaded from Harvard University's DASH repository, and is made available under the terms and conditions applicable to Other Posted Material, as set forth at http:// nrs.harvard.edu/urn-3:HUL.InstRepos:dash.current.terms-of-use\#LAA

\section{Share Your Story}

The Harvard community has made this article openly available.

Please share how this access benefits you. Submit a story.

\section{Accessibility}




\title{
EXPANSION OF DIPLOPTERYS AT THE EXPENSE OF BANISTERIOPSIS (MALPIGHIACEAE)
}

\author{
William R. ANDERSON ${ }^{1}$ AND Charles C. DAVIS ${ }^{2}$
}

\begin{abstract}
Phylogenetic analyses of molecular and morphological data have shown the genus Banisteriopsis to be polyphyletic and the genus Diplopterys to be nested within Banisteriopsis subg. Pleiopterys, which is not in the clade that contains the type of the name Banisteriopsis. Therefore, it is necessary to take up the name Diplopterys for the small genus formerly called that plus subg. Pleiopterys of Banisteriopsis. A description of the amplified genus Diplopterys is provided, two new species are described (D. bahiana and D. carvalhoi), and the following new combinations in Diplopterys are proposed, with all combinations by W. R. Anderson and C. Cav. Davis: D. amplectens, D. cachimbensis, D. caduciflora, D. cristata, D. erianthera, D. heterostyla, $D$. hypericifolia, D. krukoffii, D. leiocarpa, D. longialata, D. lucida, D. lutea, D. nigrescens, D. nutans, D. patula, D. peruviana, D. platyptera, D. populifolia, D. pubipetala, D. rondoniensis, D. schunkei, D. sepium, D. valvata, D. virgultosa, and D. woytkowskii. Illustrations are provided for D. bahiana, D. cabrerana, D. carvalhoi, D. pauciflora, D. pubipetala, and D. valvata.
\end{abstract}

Keywords: Banisteriopsis, Diplopterys, Malpighiaceae.

Malpighiaceae are a largely Neotropical family of flowering plants, many of which produce wind-dispersed samaras. In most of the larger genera that produce samaras, some species "have had the principal wing(s) reduced or lost, often augmented by new supernumerary winglets or various kinds of aerenchyma or airfilled chambers" (Anderson, 2001: 85). One example of such reduction is Diplopterys A. Juss., which resembles species of Banisteriopsis C. B. Rob. in its flowers but produces a mericarp that lacks the dorsal wing of Banisteriopsis. Niedenzu (1928) muddied the waters by adding to Diplopterys three genera that are not closely related to it, Jubelina A. Juss., Malpighiodes Nied., and Mezia Nied. (Anderson, 1981, 1990, 2006). Gates (1982) clarified the situation by restricting Diplopterys to its type, D. paralias A. Juss. [D. pauciflora (G. Mey.) Nied.], plus three species that were unknown to Niedenzu. She recognized the close relationship of Diplopterys and Banisteriopsis but chose to maintain them as separate genera because of their strikingly different fruits.
Gates recognized three subgenera in Banisteriopsis: Banisteriopsis, Hemiramma (Griseb.) B. Gates, and Pleiopterys (Nied.) B. Gates. She identified the closest relatives of Diplopterys as species in Banisteriopsis subg. Pleiopterys sect. Anisopterys (Griseb.) B. Gates. Our recent phylogenetic analysis of Malpighiaceae from combined molecular and morphological data (C. Davis and W. Anderson, unpubl. data) has revealed that Banisteriopsis is not monophyletic, even if Diplopterys is included in Banisteriopsis. Although the proper disposition of subgenera Banisteriopsis and Hemiramma is not entirely clear, we know from the available data that Diplopterys is embedded in Banisteriopsis subg. Pleiopterys (Fig. 1) and that this clade is distinct from the one containing the lectotype of Banisteriopsis; the latter clade is more closely related to the gaudichaudioids (sensu Davis et al., 2001). Of the species included in our analyses, D. cabrerana (Cuatrec.) B. Gates is a strongly supported sister to B. hypericifolia (A. Juss.) W. R. Anderson \& B. Gates, a species of subg. Pleiopterys sect. Anisopterys, and that

We thank Kenneth J. Wurdack for sequencing Banisteriopsis cornifolia, André Amorim (CEPEC) and Gert Hatschbach (MBM) for sending specimens to serve as the types for our new species, and Christiane Anderson and Kanchi Gandhi for contributing helpful comments on the manuscript. Karin Douthit drew the beautiful illustrations.

${ }^{1}$ University of Michigan Herbarium, 3600 Varsity Drive, Ann Arbor, Michigan 48108-2287, U.S.A. E-mail: wra@umich.edu

${ }^{2}$ Department of Organismic and Evolutionary Biology, Harvard University Herbaria, 22 Divinity Avenue, Cambridge, Massachusetts 02138-2094, U.S.A. E-mail: cdavis@oeb.harvard.edu 


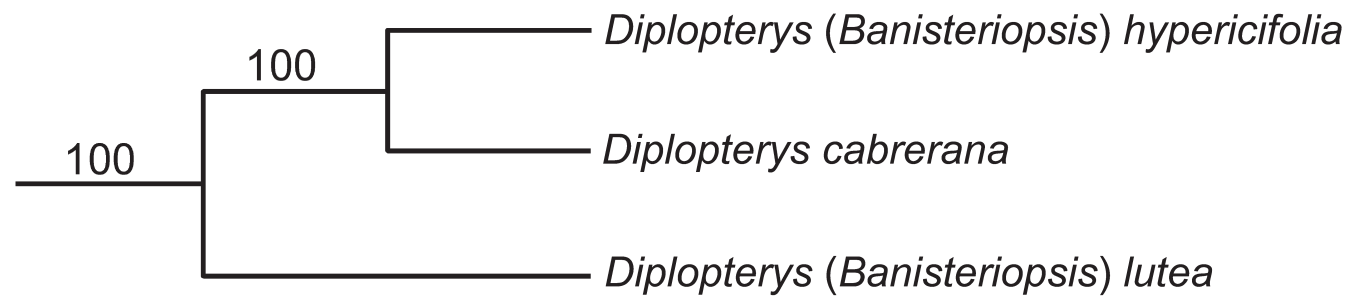

FIGURE 1. Phylogenetic tree for three species of Malpighiaceae, representing Diplopterys in the expanded sense adopted in this paper (Diplopterys plus Banisteriopsis subg. Pleiopterys). The parsimony tree shown here is extracted from a larger phylogenetic analysis of Malpighiaceae using combined DNA sequences from plastid matK, $n d h F$, and $r b c L$, nuclear $P H Y C$, and morphology; all genes were sequenced for all taxa (C. Davis and W. Anderson, unpubl. data). Bootstrap values are given above branches. Vouchers for collections sequenced: D. cabrerana, Burnham 1774 (MICH); D. hypericifolia, Anderson 13638 (MICH); D. lutea, Fairchild Tropical Garden 60-85 (FTG).

pair is strongly supported as sister to B. lutea (Griseb.) Cuatrec., a species of subg. Pleiopterys sect. Sciurostylis (Skottsb.) B. Gates (Fig. 1). From these observations we can conclude that (1) Gates was correct in her assessment of the systematic position of Diplopterys; it does belong with the species she assigned to Banisteriopsis subg. Pleiopterys; (2) Banisteriopsis as she recognized it is polyphyletic and must be reconfigured, excluding the species of subg. Pleiopterys as well as Diplopterys. There are two generic names available for that group of species, Diplopterys and Jubistylis Rusby, with Diplopterys having priority. In this paper we provide a description of the amplified Diplopterys, transfer to Diplopterys all of the species assigned by Gates to Banisteriopsis subg. Pleiopterys except for one that we do not accept as distinct, and describe two new species of Diplopterys.

Gates (1982) pointed out in defense of Diplopterys that in addition to having fruits without dorsal wings, the species she assigned to the genus also differ from most species of Banisteriopsis in their lingulate, spreading bracts and bracteoles, although she readily admitted that identical bracts and bracteoles are found in two species of Banisteriopsis subg. Pleiopterys that have a samara with a welldeveloped dorsal wing, B. krukoffii B. Gates and B. patula B. Gates. One of her four species of Diplopterys, however, D. mexicana B. Gates, was (and still is) known only from its type, which bore no fruits. Given that Diplopterys is embedded in Banisteriopsis subg. Pleiopterys, it seems quite possible that when $D$. mexicana is collected with fruits, they will prove to be samaras with a dorsal wing like those of $B$. krukoffii and $B$. patula, rather than reduced fruits like those of the three South American species of Diplopterys sensu stricto. Indeed, the disjunction of the Mexican endemic D. mexicana (the nearest species with lingulate bracts and bracteoles is in Amazonian Colombia) will be easier to understand if it bears a winged samara, which might have helped it achieve such a surprising range extension.

Because our taxonomy so closely mirrors that in the excellent monograph by Gates (1982), we are not providing a key to species here. Gates's key to flowering specimens will lead the user of that paper to Diplopterys or Banisteriopsis subg. Pleiopterys, and her key to fruiting specimens of Banisteriopsis will identify all the species treated here except those with reduced fruit wings, which are distinguished in her key to the species of Diplopterys. The only exceptions are our new species, D. bahiana W. R. Anderson \& C. Cav. Davis, which comes out in Gates's key with $B$. virgultosa (A. Juss.) W. R. Anderson \& B. Gates or B. nigrescens (A. Juss.) B. Gates, and D. carvalhoi W. R. Anderson \& C. Cav. Davis, which will key in Gates's paper to B. nutans (Nied.) B. Gates or B. peruviana (Nied.) B. Gates. The distinguishing characteristics of these two new species are discussed below in their protologues. Our other departure from the taxonomy of Gates is to place one of her names, B. parvifolia (Nied.) B. Gates, in synonymy under B. leiocarpa (A. Juss.) B. Gates, which is treated here as a species of Diplopterys. 
Diplopterys A. Juss. in Deless., Icon. Sel. Pl. 3: 20, pl. 33. 1838 [“1837”]. TYPE: Diplopterys paralias A. Juss. in Deless. [Diplopterys pauciflora (G. Mey.) Nied. in Engl.].

Synonyms: Banisteria sect. Anisopterys Griseb., Linnaea 13: 201. 1839. Banisteriopsis sect. Anisopterys (Griseb.) B. Gates, Fl. Neotrop. Monogr. 30: 176. 1982. TYPE: Banisteria pubipetala A. Juss. in A. St.-Hil. [Diplopterys pubipetala (A. Juss.) W. R. Anderson \& C. Cav. Davis].

Banisteria subg. Pleiopterys Nied., Banisteria 2: 12. 1901. Banisteriopsis subg. Pleiopterys (Nied.) B. Gates, Fl. Neotrop. Monogr. 30: 164. 1982. LECTOTYPE, designated by Gates, 1982, p. 164: Banisteria pubipetala A. Juss. in A. St.-Hil. [Diplopterys pubipetala (A. Juss.) W. R. Anderson \& C. Cav. Davis].

Banisteria subg. Sciurostylis Skottsb., Kongl. Svenska Vetenskapsakad. Handl. 35(6): 15. 1901. Banisteriopsis sect. Sciurostylis (Skottsb.) B. Gates, Fl. Neotrop. Monogr. 30: 164. 1982. TYPE: Banisteria hassleriana Chodat [Diplopterys lutea (Griseb.) W. R. Anderson \& C. Cav. Davis].

Banisteria sect. Actinoctenia Nied., Banisteria 2: 12. 1901. LECTOTYPE, designated by Gates, 1982, p. 176: Banisteria lucida Rich. [Diplopterys lucida (Rich.) W. R. Anderson \& C. Cav. Davis].

Banisteria subsect. Anadenia Nied., Banisteria 2: 22. 1901. LECTOTYPE, designated by Gates, 1982, p. 176: Banisteria eglandulosa A. Juss. [Diplopterys patula (B. Gates) W. R. Anderson \& C. Cav. Davis].

Banisteria subsect. Octadenia Nied., Banisteria 2: 18. 1901. LECTOTYPE, designated by Gates, 1982, p. 176: Banisteria pubipetala A. Juss. in A. St.Hil. [Diplopterys pubipetala (A. Juss.) W. R. Anderson \& C. Cav. Davis].

Banisteria subsect. Psilopetalum Nied., Banisteria 2: 16. 1901. LECTOTYPE, designated by Gates, 1982, p. 164: Banisteria nitrosiodora Griseb. [Diplopterys lutea (Griseb.) W. R. Anderson \& C. Cav. Davis].
Banisteria subsect. Sericopetalum Nied., Banisteria 2: 12. 1901. LECTOTYPE, designated by Gates, 1982, p. 176: Banisteria lucida Rich. [Diplopterys lucida (Rich.) W. R. Anderson \& C. Cav. Davis].

Banisteria ser. Cyrtanthele Nied., Banisteria 2: 14. 1901. LECTOTYPE, designated by Gates, 1982, p. 176: Banisteria lucida Rich. [Diplopterys lucida (Rich.) W. R. Anderson \& C. Cav. Davis].

Banisteria ser. Orthanthele Nied., Banisteria 2: 12. 1901. LECTOTYPE, designated by Gates, 1982, p. 176: Banisteria hypericifolia A. Juss. in A. St.-Hil. [Diplopterys hypericifolia (A. Juss.) W. R. Anderson \& C. Cav. Davis]. Jubistylis Rusby, Mem. New York Bot. Gard. 7: 273. 1927. TYPE: Jubistylis mollis Rusby [Diplopterys lutea (Griseb.) W. R. Anderson \& C. Cav. Davis].

The following description of Diplopterys sensu lato is based for the most part on the descriptions of Diplopterys sensu stricto and Banisteriopsis subg. Pleiopterys found in Gates (1982).

Woody vines or shrubs, when shrubby the branches often twining. Leaves opposite; petiole eglandular or bearing 2 (rarely 4 ) glands on distal half; lamina with glands (often minute) on or just within margin (on the abaxial surface in 1 species); stipules interpetiolar, distinct, small to minute. Inflorescence axillary or occasionally terminal, of 4- to 6-flowered umbels borne singly or in short racemes or cymes, or condensed axillary racemes of up to 8 pairs of flowers; bracts and bracteoles eglandular, persistent; pedicels sessile. Flowers bilaterally symmetrical in both corolla and androecium. Sepals all eglandular or the lateral 4 biglandular and the anterior eglandular, the glands when present mostly attached below free part of sepal. Petals yellow, glabrous or abaxially sparsely to densely sericeous, the posterior petal different in size, shape, and stance from the lateral 4. Stamens 10, all fertile, the connective with projecting convex cells or papillae. Gynoecium 3-carpellate, the carpels distinct in the ovary, 1 anterior and 2 posterior; styles 3 , distinct, hairy at least at base or up to $2 / 3$ of their length; stigmas terminal and capitate or occasionally truncate. Fruit dry, schizocarpic, 
comprising 3 mericarps (or fewer by abortion) separating from a low pyramidal torus; nut of mericarp smooth-sided, rugose, ribbed, or bearing diverse winglets, and in most species bearing a well-developed dorsal wing thickened on the adaxial edge with the veins bending toward the thinner abaxial edge, usually bearing a triangular or rounded appendage on adaxial edge at base; dorsal wing reduced to a crest in 4 species; locule of mericarp glabrous within; carpophore present or absent. Chromosome number: $n=10$ (in D. hypericifolia [Gates, 1982] and D. valvata [Anderson, 1993]).

Diplopterys in the expanded sense adopted here comprises 31 species of the Neotropics (one in Mexico, one in Costa Rica, two in Panama, one in Trinidad, and 30 in South America).
Diplopterys amplectens (B. Gates) W. R. Anderson \& C. Cav. Davis, comb. nov.

Basionym: Banisteriopsis amplectens B. Gates, Fl. Neotrop. Monogr. 30: 189. 1982. TYPE: BRAZIL. Mato Grosso: Mun. Alto Araguaia, 22 Jul. 1974, G. Hatschbach 34693 (Holotype: MBM; Isotypes: $\mathrm{MICH}, \mathrm{Z}$ ).

Distribution: eastern and southern Brazil.

Diplopterys bahiana W. R. Anderson \& C. Cav. Davis, sp. nov. TYPE: BRAZIL. Bahia: Mun. Macaúbas, Rodovia Macaúbas a Bom Jesus da Lapa, entre o alto da Serra Poções e a Lagoa do Maurício [ca. $13^{\circ} \mathrm{S}, 42^{\circ} 50^{\prime} \mathrm{W}$; caatinga; 15 Jun. 2004 (fl/fr), G. Hatschbach, M. Hatschbach \& O. S. Ribas 77886 (Holotype: MBM; Isotype: MICH). Fig. 2.
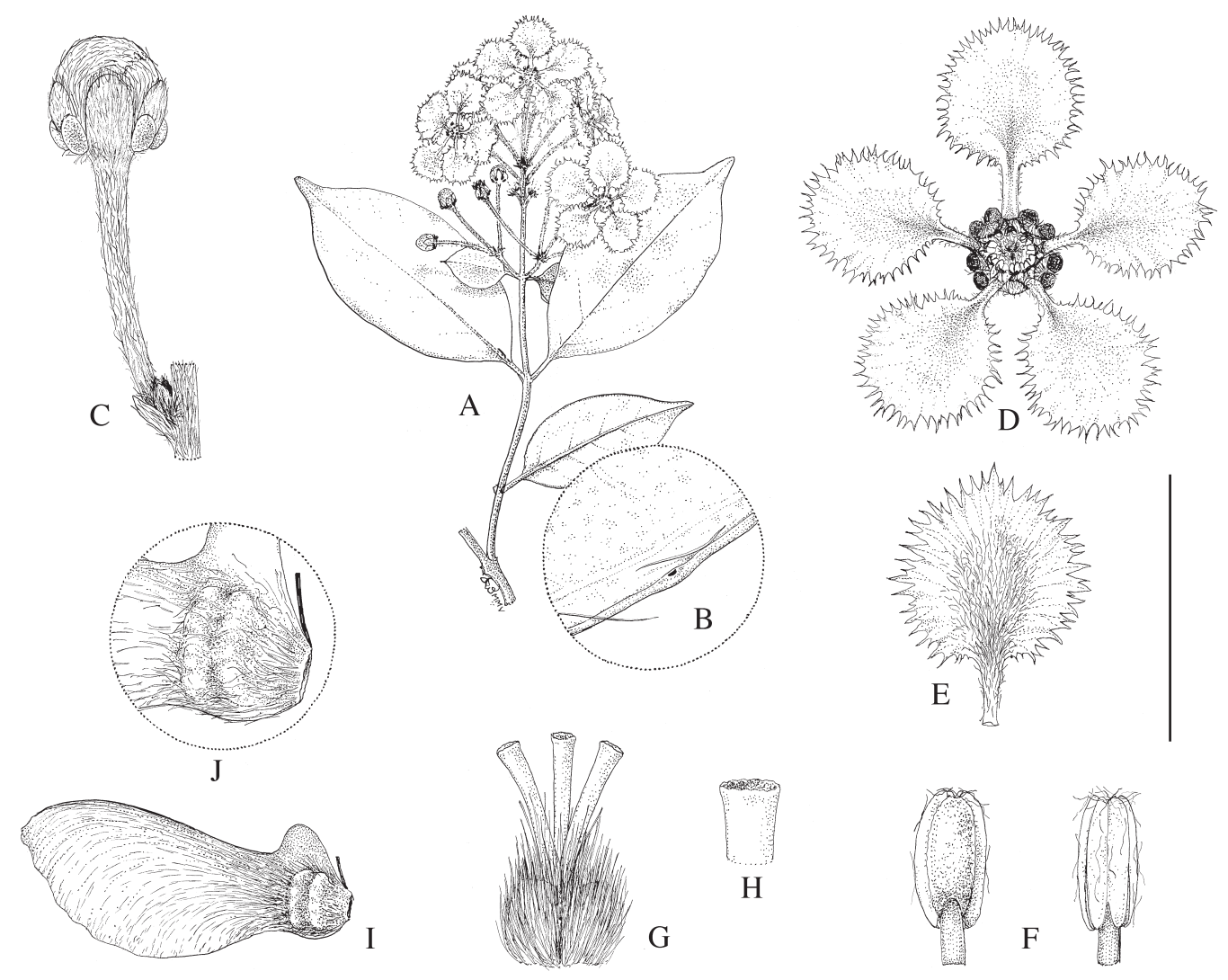

FIGURE 2. Diplopterys bahiana. A, flowering branch; B, enlargement of abaxial leaf surface to show minute marginal gland; C, flower bud; D, flower, posterior petal uppermost; E, lateral petal, abaxial view; F, anthers, abaxial view (left) and adaxial view (right); G, gynoecium; H, apex of style; I, samara (most hairs removed from nut); J, enlargement of nut of samara. Scale bar $=6 \mathrm{~cm}(\mathrm{~A}) ; 2 \mathrm{~mm}(\mathrm{~B}, \mathrm{H}) ; 1 \mathrm{~cm}(\mathrm{C}, \mathrm{J}) ; 2 \mathrm{~cm}(\mathrm{D}, \mathrm{I}) ; 1.5$ $\mathrm{cm}(\mathrm{E}) ; 4 \mathrm{~mm}(\mathrm{~F}, \mathrm{G})$. Drawn from Hatschbach et al. 77886 (MICH). 
Liana lignosa, caulibus sericeis vel demum glabrescentibus; lamina foliorum majorum $3.7-6.3 \mathrm{~cm}$ longa, $2.0-2.8 \mathrm{~cm}$ lata; petiolus 3-4 mm longus, aureo-sericeus vel demum glabrescens; axis inflorescentiae sericeus; flores in umbella 4-flora portati; pedicelli 19-22 mm longi, sericei; petala lutea, abaxialiter dense sericea, margine lacerata; antherae sparsim tomentosae; styli ca. $2 \mathrm{~mm}$ longi, subaequales; samara 21-24 mm longa, ala dorsali 16-20 mm longa, 9-12 mm lata, basi appendice 1.5-3.0 mm alta instructa, nuce in quoque latere 2 cristis crassis ala dorsali parallelis instructa.

Woody vine; stems initially loosely sericeous, glabrescent (in second year?) and developing lenticels. Lamina of larger leaves $3.7-6.3 \mathrm{~cm}$ long, $2.0-2.8 \mathrm{~cm}$ wide, elliptical, cuneate at base, acuminate at apex, flat or slightly falcate, glabrescent at maturity with the abaxial midrib thinly sericeous and with scattered straight appressed hairs on abaxial surface, especially at base, several minute glands impressed in margin, the principal lateral veins 7-9 on each side; petiole 3-4 mm long, goldensericeous or eventually glabrescent, eglandular; stipules $0.3-0.5 \mathrm{~mm}$ long, triangular, borne on stem beside petioles, persistent or deciduous. Inflorescences axillary or terminal, an umbel of 4 flowers raised on a sericeous stalk 3-6 mm long, occasionally (?) with an additional pair of flowers borne slightly below the terminal umbel; bracts and bracteoles ca. $1 \mathrm{~mm}$ long and wide, ovate, appressed, abaxially sericeous, adaxially glabrous, eglandular, persistent; pedicel sessile, 19-22 mm long, sericeous with the hairs whitish. Sepals $1.0-1.5 \mathrm{~mm}$ long beyond glands, $1.5-1.7 \mathrm{~mm}$ wide, rounded, abaxially densely sericeous, adaxially glabrous, appressed in anthesis, the lateral 4 biglandular with the glands $1.5-2.0 \mathrm{~mm}$ long and 1.0-1.3 $\mathrm{mm}$ wide, the glands attached mostly below free part of sepal, the anterior sepal eglandular; petals yellow, abaxially densely but loosely sericeous on claw and limb (especially proximally and on margin), adaxially glabrous, deeply lacerate; lateral petals with limb 8.0-9.5 $\mathrm{mm}$ long, 8.5-10.0 mm wide, orbicular, the claw $3 \mathrm{~mm}$ long; posterior petal similar to lateral petals but with a thicker claw (not constricted at apex) and often a somewhat smaller limb, more deeply and finely divided on margin; filaments glabrous, distinct or connate at base, \pm straight, $1.5-2.5 \mathrm{~mm}$ long, shortest opposite anterior-lateral petals; anthers sparsely tomentose distally on locules, 1.3-1.8 $\mathrm{mm}$ long, those opposite sepals longer and with apically more swollen connectives than those opposite petals, the connectives not exceeding locules; ovary ca. $1.5 \mathrm{~mm}$ high, densely darkbrown-sericeous; styles subequal, ca. $2 \mathrm{~mm}$ long, erect and straight, sericeous proximally with straight erect hairs and distally glabrous, the stigmas capitate or truncate. Samara (slightly immature?) densely sericeous, especially on nut, 21-24 mm long; dorsal wing 16-20 mm long, 9-12 mm wide, bearing at adaxial base a rounded-triangular appendage 3-4 mm long, 1.5-3.0 mm high; nut 3-4 × 2-3 $\mathrm{mm}$, bearing on both sides 2 thick dissected ridges parallel to each other and to base of dorsal wing; carpophore rudimentary, ca. $0.7 \mathrm{~mm}$ long and $0.3 \mathrm{~mm}$ wide.

Phenology: the only known collection was found with flowers and fruits in June.

Ecology and Distribution: known from open dry vegetation in central Bahia, Brazil.

This species is named for the Brazilian state of Bahia, source of the type. In the key by Gates (1982) it comes out to Banisteriopsis virgultosa (A. Juss.) W. R. Anderson \& B. Gates [Diplopterys virgultosa (A. Juss.) W. R. Anderson \& C. Cav. Davis] or B. nigrescens (A. Juss.) B. Gates [D. nigrescens (A. Juss.) W. R. Anderson \& C. Cav. Davis]. The samara of $D$. virgultosa is similar in size to that here, but its nut is smooth-sided and the leaf has a very short petiole and an orbicular lamina that is cordate at the base. In $D$. nigrescens the ridges on the nut of the samara radiate from the areole, rather than lying parallel to the dorsal wing as in this species, and its petals are only sparsely sericeous. In flower $D$. bahiana resembles D. pubipetala (A. Juss.) W. R. Anderson \& C. Cav. Davis, which is common in Bahia, but the samara of that species bears several welldeveloped winglets on the sides of the nut, very different from the thick ridges found in D. bahiana.

A possible second collection of Diplopterys bahiana is Lewis et al. SPF 37240 (MICH), from Rio de Contas, in the same region of Bahia as that where the type was collected. We are not treating it as a paratype because it differs in some respects from the type of D. bahiana. In 1980, Gates identified this collection as Banisteriopsis nigrescens, but it does not fit her description of $B$. nigrescens. Its very immature 
fruits seem to have lateral crests similar to those of D. bahiana. A decision as to the identity of the collection by Lewis et al. will have to await the availability of more and better collections.

Diplopterys cabrerana (Cuatrec.) B. Gates, Brittonia 31: 109. 1979.

Basionym: Banisteriopsis cabrerana Cuatrec., Webbia 13: 493. 1958. TYPE: COLOMBIA. Vaupés: Río Piraparaná, 9 Sep. 1952, R. E. Schultes \& I. Cabrera 17297 (Holotype: US). Fig. 3.

Distribution: Amazonian South America.

Diplopterys cachimbensis (B. Gates) W. R. Anderson \& C. Cav. Davis, comb. nov.

Basionym: Banisteriopsis cachimbensis B. Gates, Fl. Neotrop. Monogr. 30: 185. 1982. TYPE: BRAZIL. Pará: Serra do Cachimbo, 21 Feb. 1977, J. Kirkbride \& E. Lleras 2957 (Holotype: INPA; Isotype: $\mathrm{MICH})$.

Distribution: central and southern Brazil.

Diplopterys caduciflora (Nied.) W. R. Anderson \& C. Cav. Davis, comb. nov.

Basionym: Banisteria caduciflora Nied., Banisteria 2: 22. 1901. Banisteriopsis caduciflora (Nied.) B. Gates, Fl. Neotrop. Monogr. 30: 198. 1982. TYPE: PERU. Loreto: Maynas, Yurimaguas, E. F. Poeppig 2474 (Holotype: $\mathrm{B} \dagger$; Isotypes: $\mathrm{F}, \mathrm{W}$ ).

Distribution: western Amazonian South America.

Diplopterys carvalhoi W. R. Anderson \& C. Cav. Davis, sp. nov. TYPE: BRAZIL. Bahia: Mun. Ilhéus, Fazenda Sultão, ramal que liga Rod. BR 415 (Ilhéus/Itabuna) ao povoado Japu, desvio a esquerda, a $2 \mathrm{~km}$ da entrada, mata estragada, 17 Feb. 1982 (fr), L. A. M. Silva, A. M. V. de Carvalho \& T. S. dos Santos 1561 (Holotype: CEPEC; Isotypes: MBM, MICH). Fig. 4.

Liana lignosa, caulibus mox glabratis; lamina foliorum majorum 7-12 cm longa, 3.0-7.5 $\mathrm{cm}$ lata, mox glabrata; petiolus $11-23 \mathrm{~mm}$ longus, glaber; axis inflorescentiae sparsissime sericeus vel glabratus; flores in umbella 4(-5)flora portati; pedicelli 20-35 mm longi, sparsissime sericei vel glabrati; calycis glandulae 4.3-4.5 mm longae, $1.5-2.5 \mathrm{~mm}$ latae; petala lutea, abaxialiter dense sericea; antherae tomentosae; styli 3.0-3.5 mm longi, aequales vel subaequales; samara 83-108 $\mathrm{mm}$ longa, ala dorsali 70-95 $\mathrm{mm}$ longa, 26-34 $\mathrm{mm}$ lata, basi appendice 8-10 mm alta instructa, nuce in quoque latere 8-12 alulis 3-6 mm latis e areola ventrali radiantibus instructa.

Woody liana; stems smooth, shining, apparently glabrous but actually very sparsely sericeous with scattered straight appressed hairs $0.2-0.3 \mathrm{~mm}$ long, soon nearly or quite glabrate. Lamina of larger leaves 7-12 cm long, 3.0-7.5 $\mathrm{cm}$ wide, elliptical or somewhat obovate, cuneate to rounded at base, abruptly acuminate at apex, falcate, glabrous at maturity or bearing a few minute appressed hairs on abaxial midrib, with many tiny glands impressed in margin and evenly distributed between base and apex, the principal lateral veins 4-6 on each side; petiole 11-23 mm long, glabrous, eglandular; stipules $0.3-0.5 \mathrm{~mm}$ long, triangular, borne on stem between petioles, mostly soon deciduous and leaving a scar. Inflorescences axillary or terminal, unbranched or ternate, terminating in an umbel of 4(-5) flowers subtended by a proximal pair of flowers up to $6 \mathrm{~mm}$ below, the axis very sparsely sericeous to glabrate; bracts 1.0-1.6 $\mathrm{mm}$ long and wide, triangular or ovate, appressed, abaxially sparsely sericeous, adaxially glabrous, eglandular, persistent; bracteoles like bracts but mostly smaller; pedicel sessile, 20-35 mm long, very sparsely sericeous with the scattered hairs like those on stem, to glabrate. Sepals $0.5-1.0 \mathrm{~mm}$ long beyond glands, $1.5-2.0 \mathrm{~mm}$ wide, broadly rounded, appressed in anthesis, abaxially thinly sericeous, adaxially glabrous, the lateral 4 biglandular with the crowded glands 4.3-4.5 $\mathrm{mm}$ long and $1.5-2.5 \mathrm{~mm}$ wide, the anterior eglandular but mostly hidden by glands on adjacent sepals, the glands $1 / 3-1 / 2$ attached to free part of sepal and $1 / 2$ or more decurrent onto receptacle; petals yellow, abaxially densely appressed-sericeous on limb and claw, adaxially glabrous, the lateral 4 strongly reflexed in anthesis, the posterior with the claw erect and the limb reflexed; anterior-lateral petals with limb 9-11 mm long, 8-11 mm wide, erose on margin, the claw $2.5-3.0 \mathrm{~mm}$ long; posteriorlateral petals with limb smaller, $8 \mathrm{~mm}$ long, 7-8 $\mathrm{mm}$ wide, short-fimbriate, the claw $2.0-2.5 \mathrm{~mm}$ long; posterior petal with limb 7.5-8.0 mm long, $6.5-7.5 \mathrm{~mm}$ wide, short-fimbriate with some proximal fimbriae glandular-thickened, 


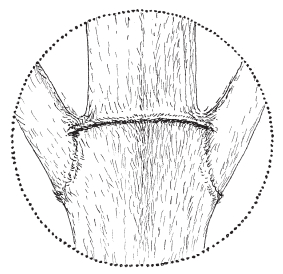

$\mathrm{C}$
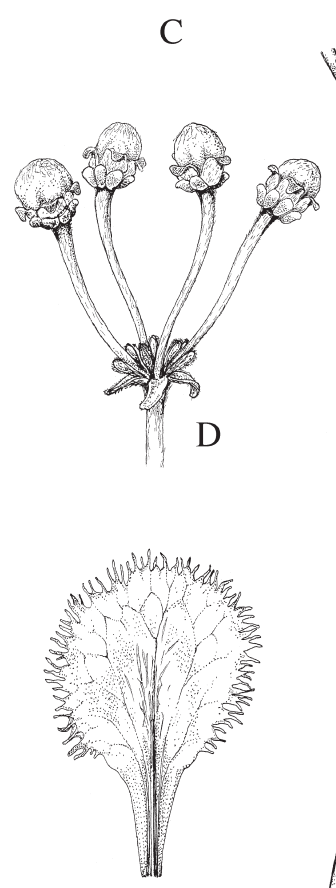

$\mathrm{E}$

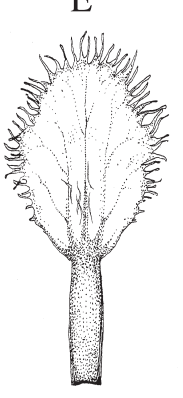

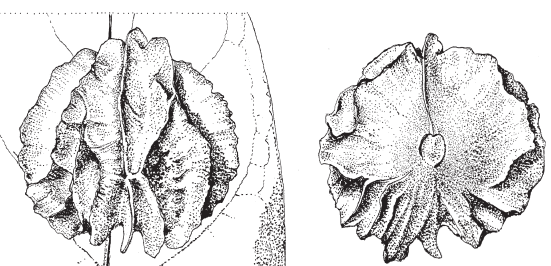

$\mathrm{H}$

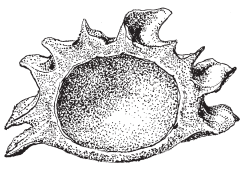

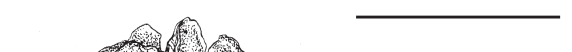
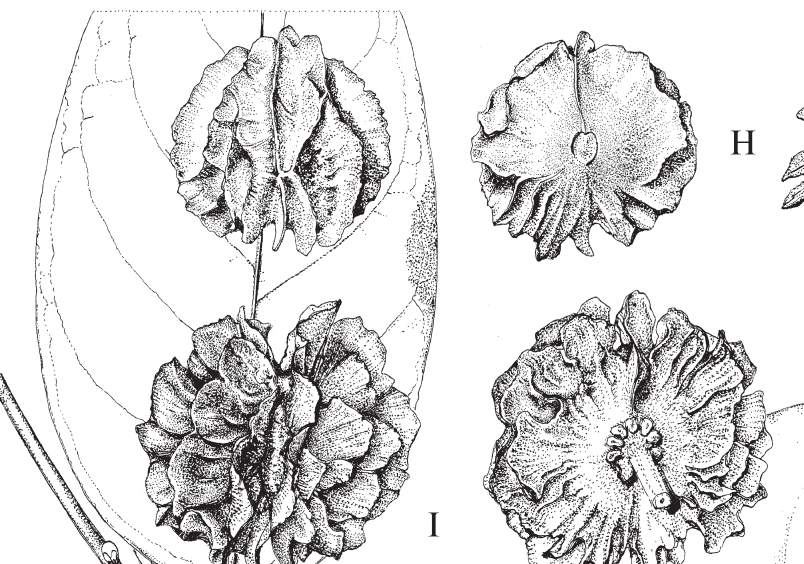


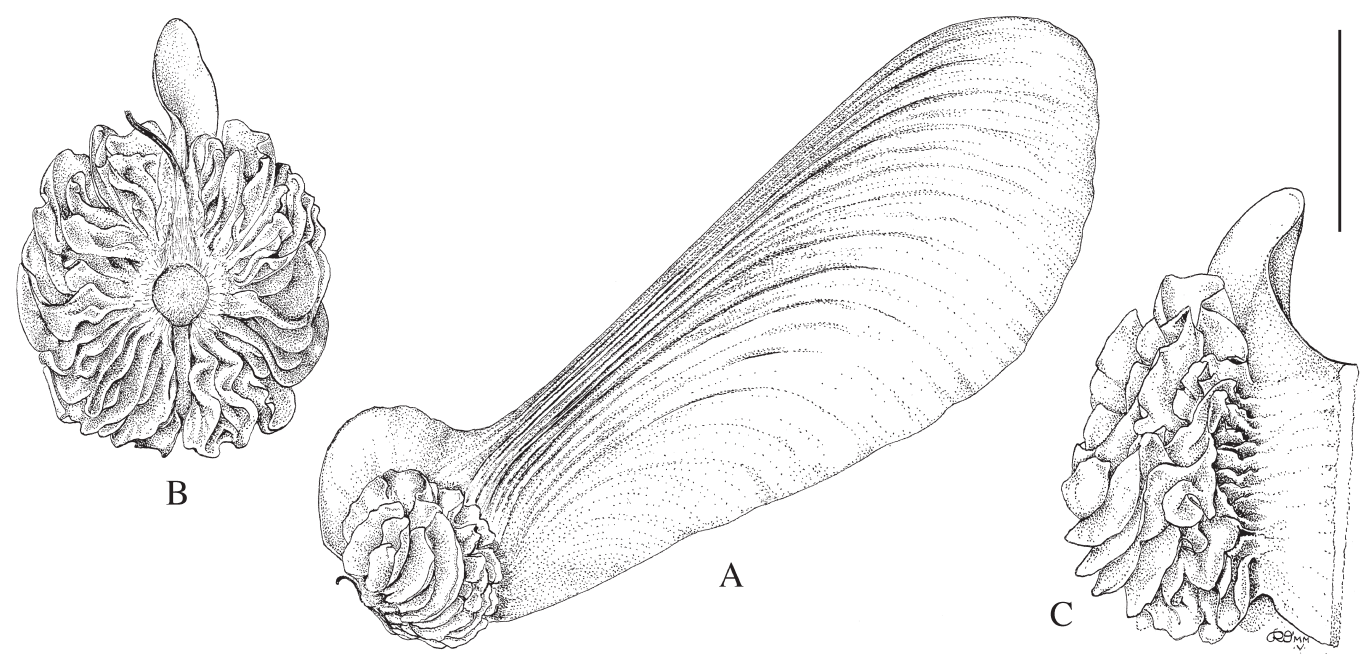

Figure 4. Diplopterys carvalhoi. A, samara; B, nut of samara from below, with ventral areole in center and carpophore below areole; $\mathrm{C}$, nut of samara from above, looking down dorsal wing. Scale bar $=2 \mathrm{~cm}(\mathrm{~A}) ; 1.3$ $\mathrm{cm}(\mathrm{B}, \mathrm{C})$. Drawn from Carvalho et al. $4118(\mathrm{MICH})$.

the claw $3.5 \mathrm{~mm}$ long, not constricted at apex; filaments glabrous, connate at base, \pm straight, 2-3 mm long, longest opposite anterior sepal, shortest opposite anterior-lateral and posterior petals; anthers tomentose on locules, 1.5-2.2 $\mathrm{mm}$ long, longer opposite sepals than opposite petals, smallest opposite posterior petal, the connective glandular-swollen and, opposite sepals, \pm exceeding locules; ovary $1.3 \mathrm{~mm}$ high, short-sericeous, all 3 locules fertile; styles equal or subequal, $3.0-3.5 \mathrm{~mm}$ long, erect or curved toward posterior petal, sericeous at base with long straight erect hairs and distally glabrous, the stigmas capitate. Samara very sparsely sericeous like stem, to glabrate, 83-108 mm long; dorsal wing 70-95 mm long, 26-34 mm wide, bearing at adaxial base a rounded appendage 14-20 mm long, 8-10 mm high; nut $12-20 \times 10-15 \mathrm{~mm}$, bearing on both sides 8-12 winglets $3-6 \mathrm{~mm}$ wide, radiating from ventral areole and distally interconnected to form a ruffled complex; carpophore 1.0-1.5 $\mathrm{mm}$ long and ca. $0.4 \mathrm{~mm}$ wide.

Phenology: collected once with flowers in December, and twice with fruits in February.

Ecology and Distribution: known only from wet forest near the Atlantic coast of southern Bahia, Brazil.

Paratypes. BRAZIL. Bahia: Mun. Itacaré, estrada Itacaré-Taboquinhas, $6 \mathrm{~km}$ SW de
Itacaré, loteamento da Marambaia, mata higrófila sul baiana, Dec. (fl), Amorim et al. 915 (MICH), Feb. (fr), Carvalho et al. 4118 (MICH).

We are happy to name this species in honor of André Maurício Vieira de Carvalho (1951-2002), a fine botanist who made a splendid contribution to our knowledge of the flora of Bahia.

Diplopterys carvalhoi is evidently close to $D$. nutans and D. peruviana, which were treated as part of the Banisteriopsis lucida group by Gates (1982). The most dramatic distinguishing character of $D$. carvalhoi is the enormous samara, its dorsal wing much longer and wider than that of any other species of Diplopterys (indeed, this is probably the largest banisterioid samara known). The many large winglets radiating from the areole also set it apart, as does the large appendage at the base of the dorsal wing. The species is also distinguished from its close congeners by its long petioles, pedicels, and calyx glands, and by being glabrate or nearly so on the stem, inflorescence axis, and pedicels. Gates described the claw of the posterior petal in D. lucida as constricted at the apex, which does not seem to be the case in the only flowering material of $D$. carvalhoi available to us. Diplopterys peruviana is known from a single collection made in Peru, whereas D. nutans 
is known from several collections made in Panama, Venezuela, Peru, and Bolivia (Gates, 1982).

The fruit of this species is especially interesting in the context of a comparison of Banisteriopsis and Diplopterys. Gates (1982: 209) maintained that the complex of interconnected winglets found in Diplopterys sensu stricto is not found in Banisteriopsis, but just such interconnections are present in the fruit of D. carvalhoi, a species that Gates surely would have included in Banisteriopsis. Indeed, comparison of our Figs. 3 and 4 will show how similar are the mericarps of $D$. cabrerana and $D$. carvalhoi when the dorsal wing of the latter is excluded from consideration. Because D. carvalhoi does not have the lingulate spreading bracts and bracteoles found in Diplopterys sensu stricto, we are not suggesting that it be considered a close sister to those species, but its fruit certainly serves as a good model for what was probably found in the ancestor of Diplopterys sensu stricto before the loss of the dorsal wing.

Diplopterys cristata (Griseb.) W. R. Anderson \& C. Cav. Davis, comb. nov.

Basionym: Banisteria cristata Griseb., Linnaea 22: 16. 1849. Banisteriopsis cristata (Griseb.) Cuatrec., Ciencia (México) 23: 141. 1964. TYPE: GUYANA [British Guiana]. [Pirara], M. Richard Schomburgk 594 (Holotype: GOET; Isotype: K).

Synonym: Banisteria orbicularis Nied., Repert. Spec. Nov. Regni Veg. 33: 69. 1933. TYPE: VENEZUELA. Anzoátegui: Soledad, 21 Nov. 1929, E. G. Holt \& W. Gehriger 155 (Holotype: $\mathrm{B} \dagger$; Isotypes: G, NY, US).

Distribution: Venezuela, Guyana, Suriname.

Diplopterys cururuënsis B. Gates, Fl. Neotrop. Monogr. 30: 215. 1982. TYPE: BRAZIL. Pará: Alto Tapajós, Rio Cururú, 12 Feb. 1974, W. R. Anderson 10803 (Holotype: IAN; Isotypes: MICH, NY).

Distribution: Bolivia and Pará, Brazil.

Diplopterys erianthera (A. Juss.) W. R. Anderson \& C. Cav. Davis, comb. nov. Basionym: Banisteria erianthera A. Juss., Ann. Sci. Nat. Bot., sér. 2, 13: 284. 1840. Banisteriopsis erianthera (A. Juss.) B.
Gates, Fl. Neotrop. Monogr. 30: 197. 1982. TYPE: BRAZIL. Amazonas: Rio Japurá, C. F. P. Martius s.n. (Holotype: M; Isotype: M).

Synonym: Banisteria platyptera f. grandifolia Nied., Malp. Amer. 2: 21. 1912. TYPE: PERU. Loreto: E. H. G. Ule 6705 (Holotype: $\mathrm{B} \dagger$; Isotypes: $\mathrm{G}, \mathrm{L}, \mathrm{MG}$ ).

Distribution: western Amazonian South America.

Diplopterys heterostyla (A. Juss.) W. R. Anderson \& C. Cav. Davis, comb. nov.

Basionym: Banisteria heterostyla A. Juss., Ann. Sci. Nat. Bot., sér. 2, 13: 283. 1840. Banisteriopsis heterostyla (A. Juss.) Cuatrec., Webbia 13: 491. 1958. TYPE: COLOMBIA. Magdalena: Santa Marta, C. G. Bertero 2201 (Holotype: P-JU; Isotypes: G-DC, M, NY, P).

Synonym: Banisteria jasminellum A. Juss., Ann. Sci. Nat. Bot., sér. 2, 13: 283. 1840. TYPE: COLOMBIA. Bolívar: Cartagena, Watts s.n. (Holotype: K; Isotype: P).

Distribution: Northern Colombia.

Diplopterys hypericifolia (A. Juss.) W. R. Anderson \& C. Cav. Davis, comb. nov.

Basionym: Banisteria hypericifolia A. Juss. in A. St.-Hil., Fl. Bras. Merid. 3: 42. 1833 ["1832"]. Banisteriopsis hypericifolia (A. Juss.) W. R. Anderson \& B. Gates, Contr. Univ. Michigan Herb. 11: 54. 1975. TYPE: BRAZIL. Minas Gerais: Sobrado, A. St.-Hilaire Catal. B ${ }^{1} 1691$ (Holotype: P; Isotypes: F, P).

Synonym: Banisteria rigida A. Juss., Ann. Sci. Nat. Bot., sér. 2, 13: 284. 1840. TYPE: BRAZIL. Minas Gerais: Tijuco, Vauthier 448 (Holotype: P-JU; Isotypes: F, G, P).

Distribution: eastern Brazil.

Diplopterys krukoffii (B. Gates) W. R. Anderson \& C. Cav. Davis, comb. nov.

Basionym: Banisteriopsis krukoffii B. Gates, Fl. Neotrop. Monogr. 30: 200. 1982. TYPE: BRAZIL. Amazonas: Mun. Humaitá, 23 Oct. 1934, B. A. Krukoff 6791 (Holotype: RB; Isotypes: A, BR, F, G, MICH, MO, NY, S, U, US).

Distribution: Amazonian Brazil and Venezuela. 
Diplopterys leiocarpa (A. Juss.) W. R. Anderson \& C. Cav. Davis, comb. nov.

Basionym: Banisteria leiocarpa A. Juss., Arch. Mus. Hist. Nat. 3: 395. 1843. Banisteriopsis leiocarpa (A. Juss.) B. Gates, Fl. Neotrop. Monogr. 30: 172. 1982. TYPE: PERU. Amazonas: Chachapoyas, A. Mathews 2126 (Holotype: P; Isotypes: BM, BR, G, K).

Synonym: Banisteria leiocarpa var. parvifolia Nied. in Engl., Pflanzenr. IV, 141 [Heft 93]: 451. 1928. Banisteriopsis parvifolia (Nied.) B. Gates, Fl. Neotrop. Monogr. 30: 174. 1982. TYPE: PERU. Piura: Río Huancabamba, Apr. 1912, A. Weberbauer 6063 (Lectotype, designated by Gates, 1982, p. 175: NY; Isolectotypes: F, GH, US).

Distribution: Amazonian Peru.

Diplopterys longialata (Nied.) W. R. Anderson \& C. Cav. Davis, comb. nov.

Basionym: Banisteria longialata Nied., Banisteria 2: 19. 1901. Banisteriopsis longialata (Nied.) B. Gates, Fl. Neotrop. Monogr. 30: 195. 1982. TYPE: PERU. Huánuco: Ponuzo, 1784, H. Ruiz s.n. (Holotype: $\mathrm{B} \dagger$; Isotypes: $\mathrm{F}, \mathrm{G}$ ).

Synonyms: Banisteria rusbyana Nied., Banisteria 2: 19. 1901. Banisteriopsis rusbyana (Nied.) C. V. Morton, J. Wash. Acad. Sci. 21: 487. 1931. TYPE: BOLIVIA. Beni River, 1 Jul. 1886, H. $H$. Rusby 2171 (Holotype: $\mathrm{B} \dagger$, fragment NY; Isotypes: F, GH, MICH, MO, NY, US).

Banisteria bopiana Rusby, Mem. New York Bot. Gard. 7: 275. 1927. Heteropterys bopiana (Rusby) Nied. in Engl., Pflanzenr. IV, 141 [Heft 93]: 377. 1928. TYPE: BOLIVIA. Bopi River Valley, 12 Sep. 1921, H. H. Rusby 663 (Holotype: NY; Isotype: MICH).

Distribution: Amazonian Colombia, Peru, and Bolivia.

Diplopterys lucida (Rich.) W. R. Anderson \& C. Cav. Davis, comb. nov.

Basionym: Banisteria lucida Rich., Actes Soc. Hist. Nat. Paris 1: 109. 1792. Banisteriopsis lucida (Rich.) Small, N. Amer. Fl. 25: 133. 1910. TYPE: FRENCH
GUIANA. J. B. Leblond s.n. (Holotype: $\mathrm{G}$; Isotypes: P, P-LAM).

Synonyms: Heteropterys appendiculata DC., Prodr. 1: 592. 1824. Banisteria appendiculata (DC.) A. Juss., Ann. Sci. Nat. Bot., sér. 2, 13: 284. 1840. TYPE: ST. VINCENT. Cultivated?, without collector or number (Holotype: G-DC; Isotype: P-JU 11597).

Banisteria lobulata E. Mey., Nova Acta Phys.-Med. Acad. Caes. Leop.-Carol. Nat. Cur. 12: 813. 1825. TYPE: SURINAME. E. Meyer s.n. (Holotype: $\mathrm{B} \dagger)$.

Banisteria divaricata A. Juss., Ann. Sci. Nat. Bot., sér. 2, 13: 284. 1840. TYPE: FRENCH GUIANA. L. C. M. Richard s.n. (Holotype: P; Isotype: P).

Banisteria calocarpa Miq., Linnaea 18: 53. 1844. TYPE: SURINAME. $H$. $C$. Focke 329 (Holotype: U).

Banisteria polita Miq., Stirp. Surinam. Select. 80. 1851. TYPE: SURINAME. A. Kappler 1900 (Holotype: U; Isotype: P). Diplopterys marshalliana L. Riley, Bull. Misc. Inform. [Kew] 1925: 135. 1925. TYPE: TRINIDAD. Arena Reserve, 28 May 1924, L. A. M. Riley 94 (Holotype: $\mathrm{K}$; Isotypes: $\mathrm{BM}, \mathrm{NY}$ ).

Distribution: Trinidad and South America south to Bolivia and southern Brazil.

Diplopterys lutea (Griseb.) W. R. Anderson \& C. Cav. Davis, comb. nov.

Basionym: Banisteria lutea Griseb., Linnaea 22: 15. 1849. Banisteriopsis lutea (Griseb.) Cuatrec., Ciencia (México) 23: 141. 1964. TYPE: PERU. Andes, H. Ruiz s.n. (Isotypes: F, G).

Synonyms: Banisteria praecox Griseb., Vidensk. Meddel. Dansk. Naturhist. Foren. Kjøbenhavn 1875: 133. 1876. TYPE. BRAZIL. Minas Gerais: Lagoa Santa, E. Warming [31] (Lectotype, designated by Gates, 1982, p. 168: C).

Banisteria nitrosiodora Griseb., Abh. Königl. Ges. Wiss. Göttingen 24: 65. 1879. Banisteriopsis nitrosiodora (Griseb.) O'Donell \& Lourteig, Lilloa 9: 260. 1943. TYPE: ARGENTINA. Salta: 
Orán, Sep. 1876, E. G. Lorentz \& G. Hieronymus 486 (Holotype: GOET; Isotypes: CORD, G, GOET, NY).

Banisteria hassleriana Chodat, Bull. Herb. Boissier 6, app. 1: 16. 1898. TYPE: PARAGUAY. Central: near Ypacaray, E. Hassler 812 (Lectotype, designated by Gates, 1982, p. 168: G; Isolectotypes: G, MICH, NY).

Banisteria hispida Nied., Malp. Amer. 2: 21. 1912. TYPE: PARAGUAY. Concepción: near Centurión, between Ríos Apa and Aquidabán, K. Fiebrig 4193 (Holotype: G; Isotype: G).

Jubistylis mollis Rusby, Mem. New York Bot. Gard. 7: 274. 1927. TYPE: BOLIVIA. Bopi River, 6 Sep. 1921, $H$. H. Rusby 732 (Holotype: NY; Isotypes: GH, MICH, US).

Distribution: central and southern South America to Argentina.

Diplopterys mexicana B. Gates, Fl. Neotrop. Monogr. 30: 215. 1982. TYPE: MEXICO. Veracruz: Mun. Hidalgotitlán, 18 Aug. 1974, M. Vázquez 951 (Holotype: XAL; Isotypes: F, MEXU, MICH, XAL).

Distribution: Veracruz, Mexico.

Diplopterys nigrescens (A. Juss.) W. R. Anderson \& C. Cav. Davis, comb. nov.

Basionym: Banisteria nigrescens A. Juss. in A. St.-Hil., Fl. Bras. Merid. 3: 44. 1833 ["1832"]. Stigmaphyllon nigrescens (A. Juss.) Kuntze, Rev. Gen. Pl. 1: 89. 1891. Banisteriopsis nigrescens (A. Juss.) B. Gates, Fl. Neotrop. Monogr. 30: 183. 1982. TYPE: BRAZIL. São Paulo: near São Paulo, A. St.-Hilaire Catal. $C^{2} 1186$ (Holotype: P; Isotypes: F, P).

Synonym: Banisteria fimbriata Griseb., Linnaea 13: 191. 1839, non B. fimbriata Vell., 1829. TYPE: BRAZIL. São Paulo: F. Sellow [VI it. 304] (Holotype: B $†$; Lectotype, designated by Gates, 1982, p. 183: NY).

Distribution: Rio de Janeiro and São Paulo, Brazil.
Diplopterys nutans (Nied.) W. R. Anderson \& C. Cav. Davis, comb. nov.

Basionym: Banisteria nutans Nied., Banisteria 2: 15. 1901. Banisteriopsis nutans (Nied.) B. Gates, Fl. Neotrop. Monogr. 30: 179. 1982. TYPE: PERU. Huánuco: Cuchero, E. F. Poeppig 1497 (Holotype: $\mathrm{B} \dagger$; Isotypes: F, W).

Synonym: Banisteriopsis panamensis Cuatrec. \& Croat, Ann. Missouri Bot. Gard. 67: 860. 1981 [“1980”]. TYPE: PANAMA. Panamá: Cerro Jefe, 1 Aug. 1972, W. G. D'Arcy \& J. J. D'Arcy 6260 (Holotype: MO).

Distribution: Panama, Venezuela, Ecuador, Peru, Bolivia.

Diplopterys patula (B. Gates) W. R. Anderson \& C. Cav. Davis, comb. nov.

Basionym: Banisteriopsis patula B. Gates, Fl. Neotrop. Monogr. 30: 201. 1982, nom. nov. for Banisteria eglandulosa A. Juss., Ann. Sci. Nat. Bot., sér. 2, 13. 283. 1840, non B. eglandulosa DC., 1824. TYPE: BRAZIL. Bahia: J. S. Blanchet 1632 (Holotype: G; Isotypes: BM, F).

Distribution: eastern Brazil.

Diplopterys pauciflora (G. Mey.) Nied. in Engl., Pflanzenr. IV, 141 [Heft 91]: 230. 1928. Basionym: Triopterys pauciflora G. Mey., Prim. Fl. Esseq. 183. 1818. Tetrapterys pauciflora (G. Mey.) DC., Prodr. 1: 587. 1824. Mascagnia pauciflora (G. Mey.) Cuatrec., Webbia 13: 372. 1958. TYPE: GUYANA [British Guiana]. Essequibo, G. Meyer 332 (Holotype: GOET). Fig. 5. Synonyms: Diplopterys paralias A. Juss. in Deless., Icon. Sel. Pl. 3: 20, pl. 33. 1838 ["1837"]. TYPE: FRENCH GUIANA. $L$. C. M. Richard s.n. (Lectotype, designated here: P-JU 11738+A; Isotypes: G, P).

Diplopterys paralias var. latifolia Nied., Malpigh. Amer. 22. 1912. Diplopterys pauciflora var. latifolia (Nied.) Nied. in Engl., Pflanzenr. IV, 141 [Heft 91]: 230. 1928. TYPE: FRENCH GUIANA. No collector or number cited (Holotype: $\mathrm{B} \dagger$ ).

Distribution: eastern Brazil, Guyana, French Guiana. 


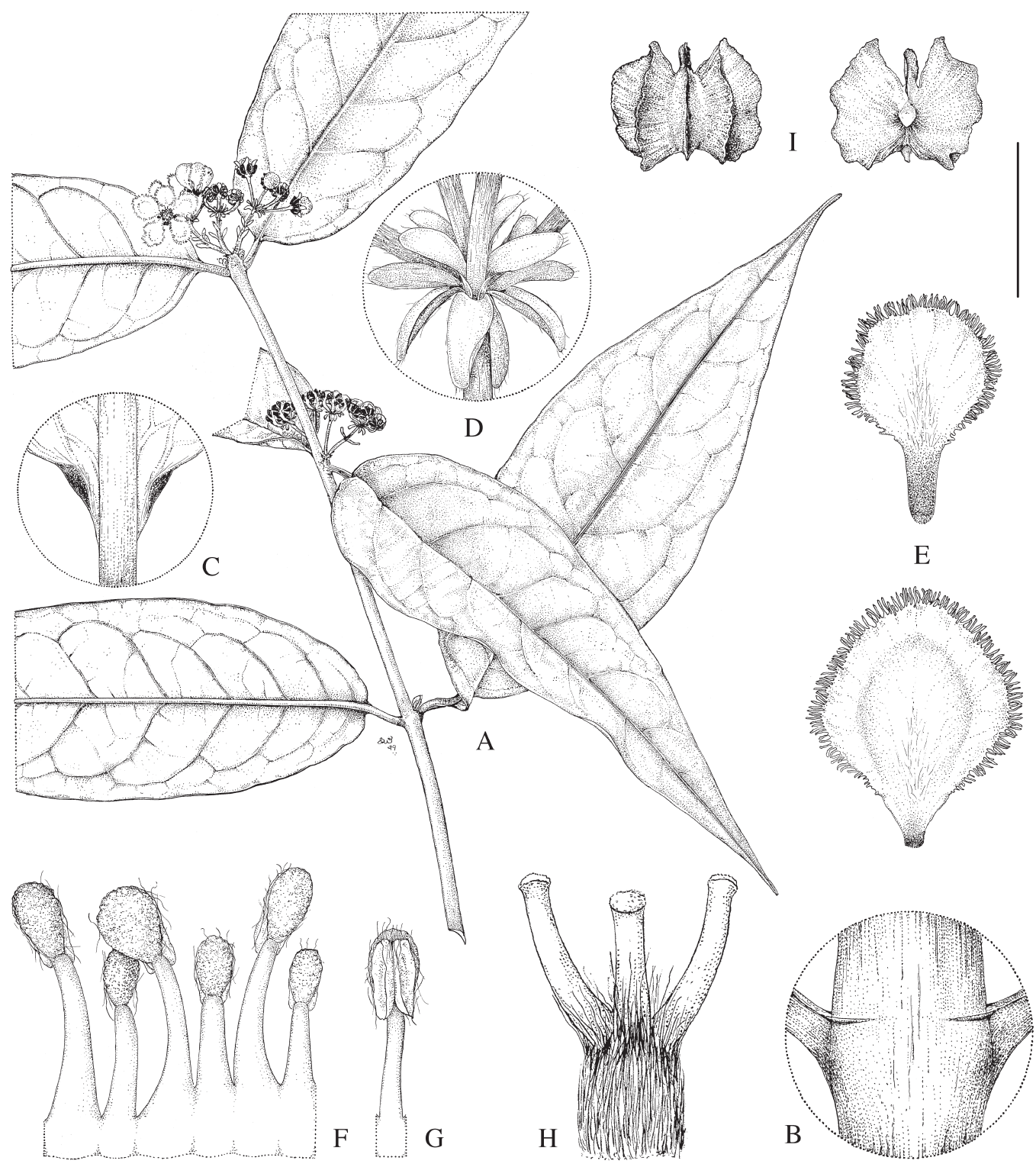

FIGURE 5. Diplopterys pauciflora. A, flowering branch; B, node to show interpetiolar stipular ridges; C, base of lamina to show marginal glands; D, base of umbel to show bracts and bracteoles; E, petals, posterior (above) and lateral (below), abaxial view; F, partial androecium laid out, abaxial view, the stamen to right opposite posterior petal; G, stamen from opposite a petal, adaxial view; H, gynoecium, anterior style in center; I, mericarps, abaxial view (left) and adaxial view (right). Scale bar $=4 \mathrm{~cm}(\mathrm{~A}) ; 4 \mathrm{~mm}(\mathrm{~B}-\mathrm{D}) ; 5 \mathrm{~mm}(\mathrm{E})$; $2 \mathrm{~mm}(\mathrm{~F}-\mathrm{H}) ; 2 \mathrm{~cm}(\mathrm{I})$. A and D-G drawn from Jacquemin 2596 (MICH); B from Arquembourg \& Dervaux $38(\mathrm{MICH})$; and $\mathrm{C}, \mathrm{H}$, and I from Granville $6856(\mathrm{MICH})$.

Diplopterys peruviana (Nied.) W. R. Anderson \& C. Cav. Davis, comb. nov.

Basionym: Banisteria peruviana Nied., Banisteria 2: 15. 1901. Banisteriopsis peruviana (Nied.) B. Gates, Fl. Neotrop.
Monogr. 30: 180. 1982. TYPE: PERU. Cajamarca: Tambillo, 18 Sep. 1878, C. Jelski 343 (Holotype: B †; Isotypes: US, W).

Distribution: Cajamarca, Peru. 
Diplopterys platyptera (Griseb.) W. R. Anderson \& C. Cav. Davis, comb. nov.

Basionym: Banisteria platyptera Griseb., Linnaea 22: 17. 1849. Banisteriopsis platyptera (Griseb.) Cuatrec., Webbia 13: 494. 1958. TYPE: VENEZUELA. Zulia: Perija, H. Karsten 55 (Holotype: GOET; Isotypes: NY, S).

Distribution: Costa Rica, Panama, Venezuela.

Diplopterys populifolia (Nied.) W. R. Anderson \& C. Cav. Davis, comb. nov.

Basionym: Banisteria populifolia Nied., Bot. Jahrb. Syst. 40: 281. 1908. Banisteria leiocarpa var. populifolia (Nied.) Nied. in Engl., Pflanzenr. IV, 141 [Heft 93]: 451. 1928. Banisteriopsis populifolia (Nied.) B. Gates, Fl. Neotrop. Monogr. 30: 175. 1982. TYPE: PERU. Amazonas: valley of Río Marañón, A. Weberbauer 4794 (Holotype: $\mathrm{B} \dagger$, fragment NY; Isotypes: $\mathrm{G}, \mathrm{MICH}$ ).

Distribution: Amazonian Peru.

Diplopterys pubipetala (A. Juss.) W. R. Anderson \& C. Cav. Davis, comb. nov.

Basionym: Banisteria pubipetala A. Juss. in A. St.-Hil., Fl. Bras. Merid. 3: 41, pl. 169. 1833 [“1832"]. Banisteriopsis pubipetala (A. Juss.) Cuatrec., Ciencia (México) 23: 142. 1964. TYPE: BRAZIL. Goiás: Villa Boa, A. St.-Hilaire Catal. $C^{1} 762$ (Lectotype, designated by Gates, 1982, p. 193: P; Isolectotypes: P). Fig. 6.

Synonyms: Banisteria spruceana Griseb. in Mart., Fl. Bras. 12(1): 45. 1858. Banisteria pubipetala f. spruceana (Griseb.) Nied., Banisteria 2: 20. 1901. TYPE: BRAZIL. Pará: near Caripi, Aug. 1849, $R$. Spruce [240] (Lectotype, designated by Gates, 1982, p. 191: GOET; Isolectotypes: C, G, GH, M, MG, NY, P, W).

Banisteria constricta Griseb. in Mart., Fl. Bras. 12(1): 46. 1858. Banisteria pubipetala f. constricta (Griseb.) Nied., Banisteria 2: 20. 1901. Banisteria pubipetala var. constricta (Griseb.) J. F. Macbr., Field Mus. Publ. Bot. 13(3): 837. 1950. TYPE: BRAZIL. Amazonas: near Barra [=Manaus], R. Spruce [1727] (Holotype: GOET; Isotypes: F, G, GH, $\mathrm{M}, \mathrm{P}, \mathrm{W})$.
Banisteria pubipetala var. oblongata Griseb., Vidensk. Meddel. Dansk. Naturhist. Foren. Kjøbenhavn 1875: 129. 1876. TYPE: BRAZIL. Minas Gerais: Lagoa Santa, E. Warming [1022] (Holotype: C).

Banisteria pubipetala var. scandens Griseb., Vidensk. Meddel. Dansk. Naturhist. Foren. Kjøbenhavn 1875: 129. 1876. TYPE: BRAZIL. Minas Gerais: Lagoa Santa, E. Warming s.n. (Holotype: presumably at $\mathrm{C}$ [not seen]).

Banisteria pearcei Rusby, Bull. New York Bot. Gard. 4: 334. 1907. TYPE: BOLIVIA. "Chailla" [Challa], M. Bang 2811 p.p. (Lectotype, designated by Gates, 1982, p. 191: NY; Isolectotype: NY).

Banisteria pubipetala f. cordata Nied. in Engl., Pflanzenr. IV, 141 [Heft 93]: 447. 1928. TYPE: PARAGUAY. Amambay: Sierra de Amambay, Aug. 1908, E. Hassler [Rojas] 10562 (Lectotype, designated by Gates, 1982: G; Isolectotypes: A, G, GH, MO, NY, P, S).

Distribution: much of South America, from Colombia and Venezuela south to northern Paraguay.

Diplopterys rondoniensis (B. Gates) W. R. Anderson \& C. Cav. Davis, comb. nov.

Basionym: Banisteriopsis rondoniensis B. Gates, Fl. Neotrop. Monogr. 30: 189. 1982. TYPE: BRAZIL. Rondônia: Guajará-Mirim, 28 Apr. 1976, M. R. Cordeiro 903 (Holotype: IAN; Isotype: $\mathrm{MICH})$.

Distribution: Rondônia, Brazil.

Diplopterys schunkei (B. Gates) W. R. Anderson \& C. Cav. Davis, comb. nov.

Basionym: Banisteriopsis schunkei B. Gates, Fl. Neotrop. Monogr. 30: 198. 1982. TYPE: PERU. San Martín: Tocache Nuevo, 10 Jan. 1971, J. Schunke V. 4635 (Holotype: F; Isotypes: G, GH, MO, NY).

Distribution: San Martín, Peru.

Diplopterys sepium (A. Juss.) W. R. Anderson \& C. Cav. Davis, comb. nov. 


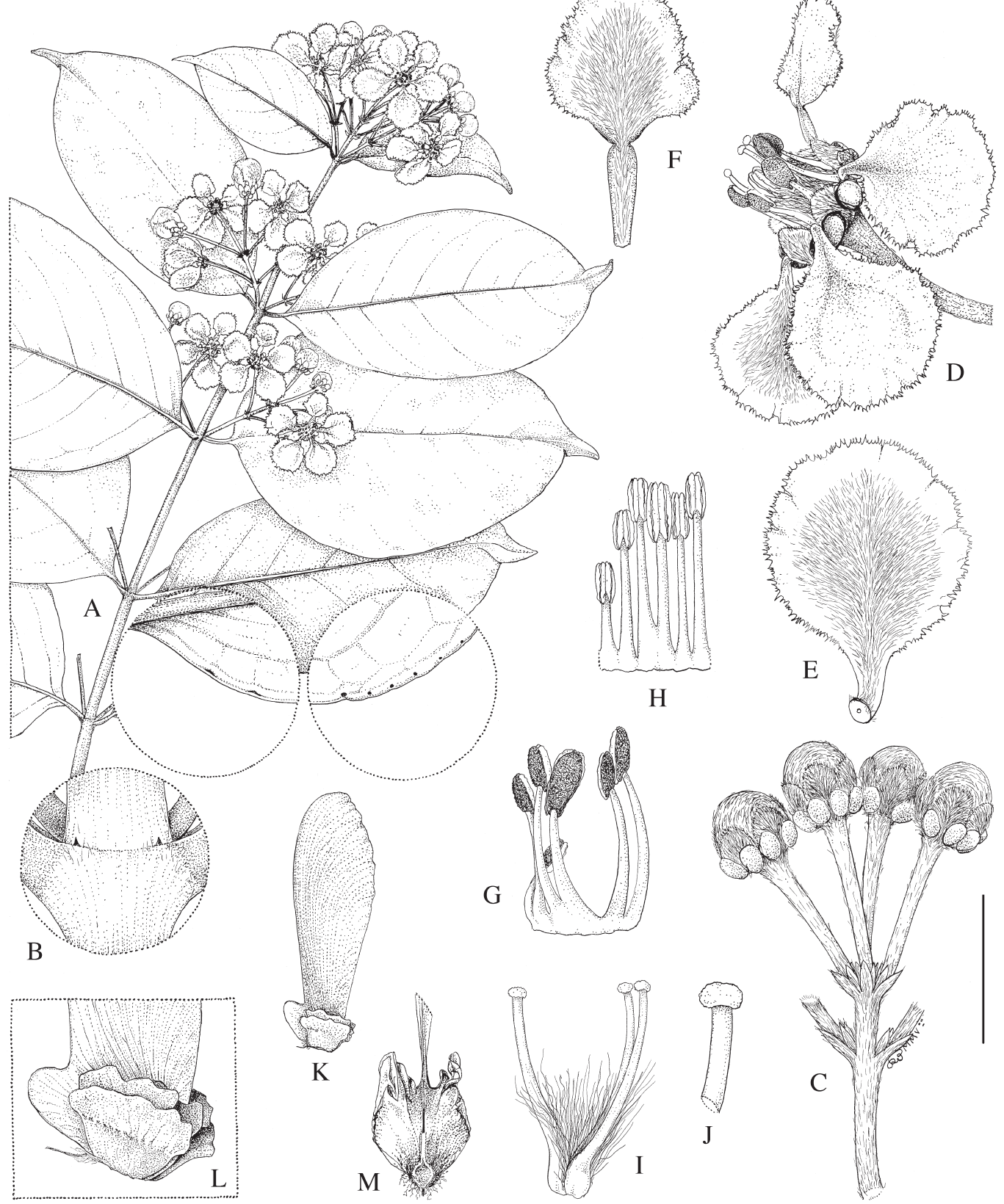

FIGURE 6. Diplopterys pubipetala. A, flowering branch (with enlargements of abaxial margin to show glands); B, node to show interpetiolar stipules; C, umbel of four flower buds with subtending pair cut away; D, flower, lateral view, posterior petal uppermost; E, lateral petal, abaxial view; F, posterior petal, abaxial view; G, portion of androecium, abaxial view, the stamen to left opposite posterior petal; $\mathrm{H}$, portion of androecium, adaxial view, with filaments straightened to show their relative lengths, the stamen to left opposite posterior petal; I, gynoecium; J, distal portion of style; K, samara; L, nut of samara enlarged to show lateral winglets; M, nut of samara, abaxial view to show carpophore. Scale bar $=4 \mathrm{~cm}(\mathrm{~A}) ; 4 \mathrm{~mm}(\mathrm{~B}, \mathrm{G}-\mathrm{I}) ; 8 \mathrm{~mm}(\mathrm{C}, \mathrm{D}, \mathrm{L}, \mathrm{M}) ; 5.7$ $\mathrm{mm}(\mathrm{E}, \mathrm{F}) ; 1.3 \mathrm{~mm}(\mathrm{~J}) ; 2 \mathrm{~cm}(\mathrm{~K})$. A and B drawn from Oliveira et al. 104 (MICH); C from Macedo 5448 (MICH); D-J from Fonseca et al. 1130 (MICH); and K-M from Kral \& Wanderley 75349 (MICH). 


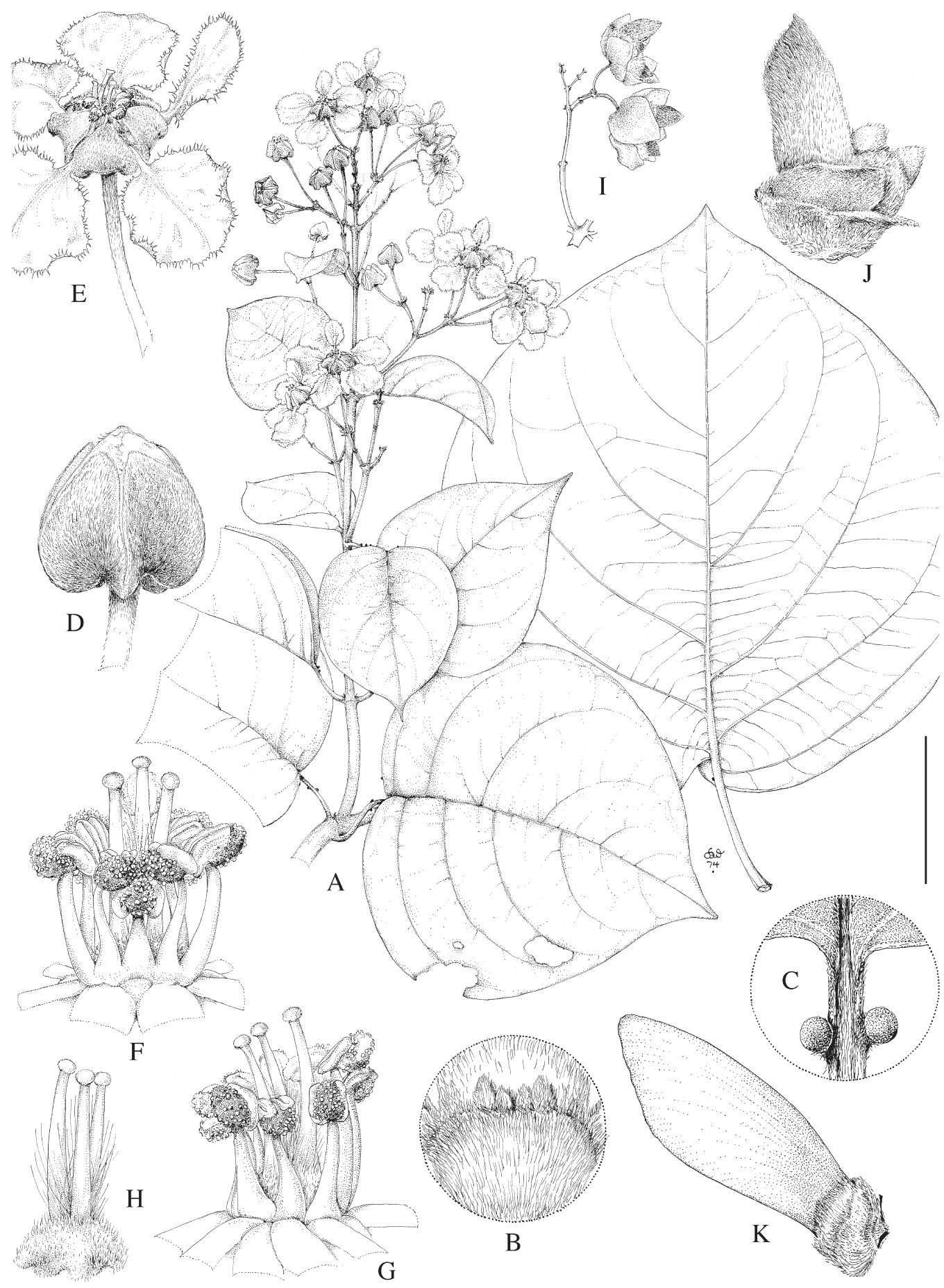

FIGURE 7. Diplopterys valvata. A, flowering branch, and abaxial view of detached large leaf; B, node with interpetiolar ridge bearing stipules; C, apex of petiole, adaxial view, to show large glands; D, flower bud; E, flower, posterior petal to right; $\mathrm{F}$, androecium and gynoecium, view from behind with short stamen opposite posterior petal in foreground; $\mathrm{G}$, androecium and gynoecium, lateral view, posterior petal to left; $\mathrm{H}$, gynoecium; I, enlarging fruits enclosed by accrescent sepals; J, immature fruit; K, samara. Scale bar = $4 \mathrm{~cm}(\mathrm{~A}, \mathrm{I})$; $4 \mathrm{~mm}$ (B, C, F-H); $8 \mathrm{~mm}$ (D); $1.3 \mathrm{~cm}$ (E, J); $2 \mathrm{~cm}$ (K). A-J drawn from Anderson et al. 36981 (MICH); K from Harley $21676(\mathrm{MICH})$. Modified from a drawing first published in Contr. Univ. Michigan Herb. 11: 52.1975. 
Basionym: Banisteria sepium A. Juss., Ann. Sci. Nat. Bot., sér. 2, 13: 284. 1840. Banisteriopsis sepium (A. Juss.) B. Gates, Fl. Neotrop. Monogr. 30: 203. 1982. TYPE: BRAZIL. Piauí: C. F. P. Martius s.n. (Holotype: M).

Distribution: Piauí and Bahia, Brazil.

Diplopterys valvata (W.R. Anderson \& B. Gates) W. R. Anderson \& C. Cav. Davis, comb. nov. Basionym: Banisteriopsis valvata W. R. Anderson \& B. Gates, Contr. Univ. Michigan Herb. 11: 51. 1975. TYPE: BRAZIL. Bahia: S of Cocos, 15 Mar. 1972, W. R. Anderson et al. 36981 (Holotype: UB; Isotypes: F, IAN, K, MICH, MO, NY, P, RB, SP, U, US). Fig. 7.

Distribution: eastern and southern Brazil.

Diplopterys virgultosa (A. Juss.) W. R. Anderson \& C. Cav. Davis, comb. nov.
Basionym: Banisteria virgultosa A. Juss., Ann. Sci. Nat. Bot., sér. 2, 13: 284. 1840. Banisteria pubipetala var. virgultosa (A. Juss.) Griseb. in Mart., Fl. Bras. 12(1): 45. 1858. Banisteriopsis virgultosa (A. Juss.) W. R. Anderson \& B. Gates, Contr. Univ. Michigan Herb. 11: 54. 1975. TYPE: BRAZIL. Tocantins ["Minas Gerais"]: Chapada do Paranã, Rio Formoso, C. F. P. Martius [1761] (Holotype: M).

Distribution: eastern Brazil.

Diplopterys woytkowskii (B. Gates) W. R. Anderson \& C. Cav. Davis, comb. nov.

Basionym: Banisteriopsis woytkowskii B. Gates, Fl. Neotrop. Monogr. 30: 181. 1982. TYPE: PERU. Pasco: Villa Rica, 13 Jun. 1962, F. Woytkowski 7328 (Holotype: MO; Isotypes: F, NY).

Distribution: Amazonian Peru.

\section{LiterATURE Cited}

ANDERSON, W. R. 1981. Malpighiaceae. The botany of the Guayana Highland. Part XI, Malpighiaceae. Mem. New York Bot. Gard. 32: 21-305. 1990. The taxonomy of Jubelina (Malpighiaceae). Contr. Univ. Michigan Herb. 17: 21-37. 1993. Chromosome numbers of neotropical Malpighiaceae. Contr. Univ. Michigan Herb. 19: 341-354.

. 2001. Malpighiaceae. Pages 82-185 in P. E. BerRy, K. YATSKIEVYCH, AND B. K. Holst, EDS., Flora of the Venezuelan Guayana. Vol. 6. Missouri Botanical Garden Press, St. Louis.
2006. Eight segregates from the neotropical genus Mascagnia (Malpighiaceae). Novon 16: 168-204.

Davis, C. C., W. R. Anderson, And M. J. DonoghuE. 2001. Phylogeny of Malpighiaceae: Evidence from chloroplast $N D H F$ and $T R N L-F$ nucleotide sequences. Amer. J. Bot. 88: 1830-1846.

GATES, B. 1982. Banisteriopsis, Diplopterys (Malpighiaceae). Flora Neotropica, Monograph 30. New York Botanical Garden, New York. 237 pp.

NiedenZu, F. 1928. Malpighiaceae. Pages 1-870 in A. Engler, ED., Das Pflanzenreich. Vol. IV, 141. Wilhelm Engelmann, Leipzig. 